\title{
Effects of Agricultural Byproducts in Ration on Productive and Reproductive Performance of Saidi Rams
}

\author{
G. A. MEGAHED ${ }^{1}$, A.-H. M. ETMAN ${ }^{2}$ \\ ${ }^{1}$ Dept. of Theriogenology, Faculty of Veterinary Medicine, Assiut University \\ ${ }^{2}$ Dept. of Animal Production (Nutrition), Faculty of Agriculture, \\ AL-Azhar University, Cairo, Egypt \\ Received October 23, 2003 \\ Accepted November 10, 2005
}

\begin{abstract}
Megahed G. A., A.-H. M. Etman: Effects of Agricultural Byproducts in Ration on Productive and Reproductive Performance of Saidi Rams. Acta Vet. Brno 2006, 75: 227-234

The influence of selected agricultural byproducts supplementation to feed rations on the ram's body gain, reproductive performance, and subsequent fertility were investigated. Forty Saidi rams were divided into 4 groups $(\mathrm{n}=10$ ). Group 1 (control) was fed $500 \mathrm{~g} / \mathrm{head} / \mathrm{day}$ concentrate feed mixtures (CFM) plus wheat straw ad libitum. Groups 2, 3 and 4 were fed $500 \mathrm{~g} / \mathrm{head} / \mathrm{day}$ CFM plus corn cobs or sugar cane tops or sugar cane bagasse (these roughages were treated with $1 \%$ urea), respectively. Serum testosterone, glucose and total cholesterol levels were determined and semen evaluations were carried out every 15 days. Testicular size, scrotal circumference and body weight were recorded each month. At the end of the experiment, 12 rams were allowed to mount 114 healthy ewes to evaluate the pregnancy rate for each group.

The results have shown that the body weight, daily body gain, testicular size and scrotal circumference increased $(p<0.01)$ in the treated groups as compared to controls with advancing age. At the end of the experiment ( 90 days), testicular size and scrotal circumference increased $(p<0.01)$ in the treated groups as compared with the control. The testosterone level $(\mathrm{ng} / \mathrm{ml})$ in treated groups increased $(2.18 \pm 0.31 \mathrm{ng} / \mathrm{ml}$ in group $2 ; 2.35 \pm 0.24 \mathrm{ng} / \mathrm{ml}$ in group 3 , and $1.97 \pm 0.16$ $\mathrm{ng} / \mathrm{ml}$ in group 4$)$ significantly $(p<0.01)$ as compared with group $1(1.76 \pm 0.09 \mathrm{ng} / \mathrm{ml})$. Moreover, supplementation of treated agricultural byproducts had a significant improving effects on the semen quality. The semen volume increased, along with individual motility and live sperm percentages. Pregnancy rate in this study indicated that rams of groups 2, 3 and 4 yielded a higher pregnancy rate $(83.33 \%, 86.67 \%$ and $81.48 \%$, respectively) than group $1(74.07 \%)$.

Agricultural byproducts such as corn cobs, sugar cane tops and sugar cane bagasse treated with $1 \%$ urea had a beneficial effect on the daily body gain and improved the reproductive performance and subsequent fertility of Saidi rams, compared to wheat straw.
\end{abstract}

Agricultural byproducts, body weight gain, testosterone, glucose, total cholesterol, testicular size, reproductive performance, rams

Sheep are believed to have been among the first mammals to be domesticated and are known to have been closely associated with humans from very early times. In Egypt, sheep rank the third most numerous domesticated ruminants for meat and milk production, after cattle and buffaloes. These animals offer the potential of making an important and continuing contribution to providing food for a growing world population (Shelt on 1995). The ration composition and its relation to the growth performance as well as reproductive efficiency (especially endocrine productions) have received great attention for a long time (Burger et al. 1987).

Experiments are still conducted to find other feed sources to replace the commonly used roughage. Agricultural feed byproducts such as straws, corn cobs, sugar cane tops and bagasse are found in large quantities in Egypt. Many investigators reported that the addition of urea improves their nutritive value (Abdel-Ghani et al. 1995; Habeeb et al. 1995). The achievement of high levels of fertility and prolificacy in sheep flocks relies not only upon the female numbers but also upon their male consorts (Gordon 1997). Moreover,

Address for correspondence:

Prof. Dr. G.A. Megahed

Dept. of Theriogenology

Faculty of Veterinary Medicine

Assiut University, Assiut, Egypt
Phone: 020882312564

Fax: 020882333938

E-mail: gabermegahed@yahoo.com

http://www.vfu.cz/acta-vet/actavet.htm 
the success of a controlled reproductive technique depends on the capability of the ram (mating activity and semen quality), when natural service is the mode of breeding. Ram fertility is important in determining the proportion of ewes that conceive. Body gain and testicular volume of rams are affected by feeding supplements containing different levels and sources of nitrogen (Murray et al. 1991; Thwaites 1994). Furthermore, a higher reproductive rate is important because it results in a larger number of young sheep available for selection, and thus leads to an accelerated genetic gain in other reproductive traits ( $\mathrm{R}$ ae 1986). The present study was conducted to determine the influence of agricultural byproducts supplementation on reproductive efficiency (testicular measurements, semen quality and hormonal profile) as well as the growth rate and fertility performance in Saidi rams.

\section{Materials and Methods}

Animals, feeds and management

Forty apparently healthy Egyptian Saidi rams with clinically normal genitalia were selected from Assiut localities for this study. At the beginning of the study, the animals were $1.5-2.5$ years old, with an average body weight of $47.65 \pm 1.89 \mathrm{~kg}$. They had previously been trained to mate occasionally. Whenever the rams failed to show any interest in mounting, the introduction of another male into the mounting area stimulated the libido of the first ram, which had shown no interest in mounting, within 5 - $10 \mathrm{~min}$. All animals grazed on Egyptian clover (Trifolium alexanderinum) and/or roughage beginning from December until the beginning of February. The animals were divided randomly into 4 groups of 10 rams each. Group 1 (control) was fed wheat straw because it is commonly used in Upper Egypt. Group 2 was fed corn cobs, Group 3 sugar cane tops, and Group 4 was given sugar cane bagasse. All animals under study were fed ad libitum and supplemented with commercial concentrate mixture at a constant amount (500 g/head/day) consisting of 50\% corn, $15 \%$ cotton seed meal, $25 \%$ soybean meal and $10 \%$ crushed barley. In addition, the rams were supplemented with mineral salts (each $100 \mathrm{~g}$ contained $25.6 \mathrm{~g}$ Na, $1.6 \mathrm{~g} \mathrm{~K}, 4.6 \mathrm{~g} \mathrm{Ca}, 1.8 \mathrm{~g} \mathrm{P}, 4.0 \mathrm{~g} \mathrm{Mg}, 300 \mathrm{mg} \mathrm{Fe}, 32 \mathrm{mg} \mathrm{Mn}, 1.5 \mathrm{mg} \mathrm{Cu}, 1.5 \mathrm{mg} \mathrm{Zn}, 1.0 \mathrm{mg}$ Co and $1.0 \mathrm{mg}$ Se). This study was carried out for 3 months and the breeding time was in May. The used agricultural byproducts, except wheat straw, were treated with $1 \%$ urea. The chemical composition of the used feed stuffs is presented in Table 1.

Table 1. Chemical composition of the experimental feedstuffs*

\begin{tabular}{|l|c|c|c|c|}
\hline Item & Group 1 & Group 2 & Group 3 & Group 4 \\
\hline Crude protein & 37.5 & 113.5 & 137.3 & 94.5 \\
\hline Ether extract & 17.6 & 24.6 & 18.2 & 17.8 \\
\hline Crude fiber & 321.5 & 257.2 & 318.5 & 351.2 \\
\hline Ash & 153.5 & 45.4 & 132.5 & 21.3 \\
\hline Nitrogen-free extract & 469.9 & 559.3 & 393.5 & 515.2 \\
\hline Organic matter & 846.5 & 954.6 & 867.5 & 978.7 \\
\hline
\end{tabular}

calculated on dry matter basis

* the values are given in $\mathrm{g} / 1000 \mathrm{~g}$

Testicular measurements and body weight

Testicular and body weight measurements were performed every month. Scrotal circumference was determined by using a flexible measuring tap. The testes were gently forced into the scrotum by applying pressure with a hand above the head of the epididymides. The testicular length, width and breadth were measured in the same way, only by using a caliper. Body weight of each ram was recorded on the same day when the testicular measurements were made.

Blood collection and serum analysis

Blood samples were collected every 15 days from all animals by jugular venipuncture and kept in an icebox, then immediately transported to the laboratory. The samples were kept at $4{ }^{\circ} \mathrm{C}$ for $6-12 \mathrm{~h}$, then the serum was separated by centrifugation at $3000 \mathrm{rpm}$ for $20 \mathrm{~min}$ and stored at $-20^{\circ} \mathrm{C}$ until analysis. Serum glucose and total cholesterol levels were determined by kits supplied by Sklavo (Italy). Serum testosterone concentrations were determined by using the ELISA kit (BIO SOURCE, Belgium, Code, 40 1700). The minimum detectable value was $0.05 \pm 0.02 \mathrm{ng} / \mathrm{ml}$ and the intra- and inter-assay coefficient variations were 6.2 and $6.4 \%$, respectively.

Semen evaluation

Semen was collected in the morning between 08.00 and $09.00 \mathrm{~h}$ once every 15 days by using an artificial vagina 
(41- $44^{\circ} \mathrm{C}$ ) and a teaser (a non-pregnant ewe or a ewe in heat). The semen was evaluated for volume, live sperm percentage and total percentage of abnormalities.

Pregnancy rate

Twelve rams (3 from each group) were allowed to mount 114 healthy ewes during breeding time (May). Pregnancy rate was calculated by abdominal palpation 120 days post mating and/or after actual lambing (We st 1986).

Statistical analysis

The data were expressed as means \pm SE for all variables, and then analyzed by using the analysis of variance (ANOVA), and means \pm SE were tested at least significant difference (LSD). All tests were done by using the PCstat computer program. Results were considered significant only at $p<0.05$ or less.

\section{Results}

The effect of feeding agricultural byproducts upon productive performance (live body weight) and reproductive performance (testicular measurements, testosterone level, semen quality, and pregnancy rate) of rams are presented in Tables $2-6$. The body weight of rams was affected by feeding on agricultural byproducts (Table 2). It significantly increased $(p<0.01)$ at the end of the experiment to $61.75 \pm 1.15$ (in the sugar cane tops group), $59.44 \pm 0.87$ (in the corn cobs group) and $57.36 \pm 1.25 \mathrm{~kg}$ (in the sugar cane bagasse group); but in the control group (wheat straw group), the body weight was $55.76 \pm 1.08 \mathrm{~kg}$. Moreover, feeding sugar cane tops resulted in a higher body gain $(13.86 \pm 0.51 \mathrm{~kg})$ and daily body gain ( $154.01 \pm 0.52 \mathrm{~g} /$ day) when compared with the control, sugar cane bagasse and corn cobs groups.

Table 2. Growth performance, serum glucose and total cholesterol levels $(\mathrm{TCH})$ of the experimental rams

\begin{tabular}{|l|c|c|c|c|}
\hline & $\mathrm{G} 1(\mathrm{n}=10)$ & $\mathrm{G} 2(\mathrm{n}=10)$ & $\mathrm{G} 3(\mathrm{n}=10)$ & $\mathrm{G} 4(\mathrm{n}=10)$ \\
\hline Initial BW (kg) & $46.89 \pm 1.56$ & $47.79 \pm 1.25$ & $47.86 \pm 1.87$ & $47.63 \pm 1.28$ \\
\hline Final BW (kg) & $55.76 \pm 1.08^{\mathrm{d}}$ & $59.44 \pm 0.87^{\mathrm{b}}$ & $61.75 \pm 1.15^{\mathrm{a}}$ & $57.36 \pm 1.25^{\mathrm{c}}$ \\
\hline Total body weight gain $(\mathrm{kg})$ & $8.75 \pm 0.36^{\mathrm{d}}$ & $11.56 \pm 0.83^{\mathrm{b}}$ & $13.86 \pm 0.51^{\mathrm{a}}$ & $10.75 \pm 0.36^{\mathrm{c}}$ \\
\hline Daily body weight gain (g/day) & $97.64 \pm 0.73^{\mathrm{d}}$ & $128.82 \pm 0.56^{\mathrm{b}}$ & $154.01 \pm 0.52^{\mathrm{a}}$ & $119.67 \pm 1.09^{\mathrm{c}}$ \\
\hline Glucose (mmol·1 $\left.{ }^{-1}\right)$ & $3.42 \pm 0.14^{\mathrm{a}}$ & $5.09 \pm 0.12^{\mathrm{b}}$ & $4.62 \pm 0.14^{\mathrm{b}}$ & $4.53 \pm 0.15^{\mathrm{b}}$ \\
\hline TCH $\left(\mathrm{mmol} \cdot 1^{-1}\right)$ & $2.17 \pm 0.07^{\mathrm{a}}$ & $0.93 \pm 0.07^{\mathrm{b}}$ & $1.09 \pm 0.05^{\mathrm{b}}$ & $1.43 \pm 0.06^{\mathrm{b}}$ \\
\hline
\end{tabular}

*means in the same row with the same superscript letters are not significantly different

* a. b. c. d $(p<0.01)$ in body weight (BW) results* a. b. c $(p<0.01)$ in serum glucose and total cholesterol

As concerns the glucose level, it was significantly lower $(p<0.01)$ in the control group (wheat straw group) when compared with those in the other groups, which were not significantly different. The total cholesterol level showed no significant variation between groups fed corn cobs, sugar cane tops and sugar cane bagasse; yet it was significantly lower $(p<0.01)$ than that in the control (wheat straw group).

The testicular size and scrotal circumference increased significantly $(p<0.01)$ in groups fed corn cobs, sugar cane tops and bagasse when compared with the group fed wheat straw (Table 3). At the end of the experimental period, the values of testicular size were 69.85 $\pm 2.09,80.54 \pm 1.87,85.75 \pm 0.86$ and $91.38 \pm 2.28 \mathrm{~cm}^{3}$ in the control (wheat straw), sugar cane bagasse, corn cobs and sugar cane tops groups, respectively. However, the scrotum circumference values were $27.8 \pm 0.82 \mathrm{~cm}$ (in wheat straw), $29.57 \pm 0.31 \mathrm{~cm}$ (in sugar cane bagasse), $30.12 \pm 0.34 \mathrm{~cm}$ (in corn cobs) and $31.62 \pm 0.54 \mathrm{~cm}$ (in sugar cane tops). Sugar cane tops had a significant increasing effect $(p<0.01)$ on the testicular size and scrotum circumference values than that in the sugar cane bagasse and corn cobs groups.

The variation in serum testosterone (means $\pm \mathrm{SE}$ ) throughout the experimental period is shown in Table 4. Serum concentrations of testosterone showed changes. They increased 


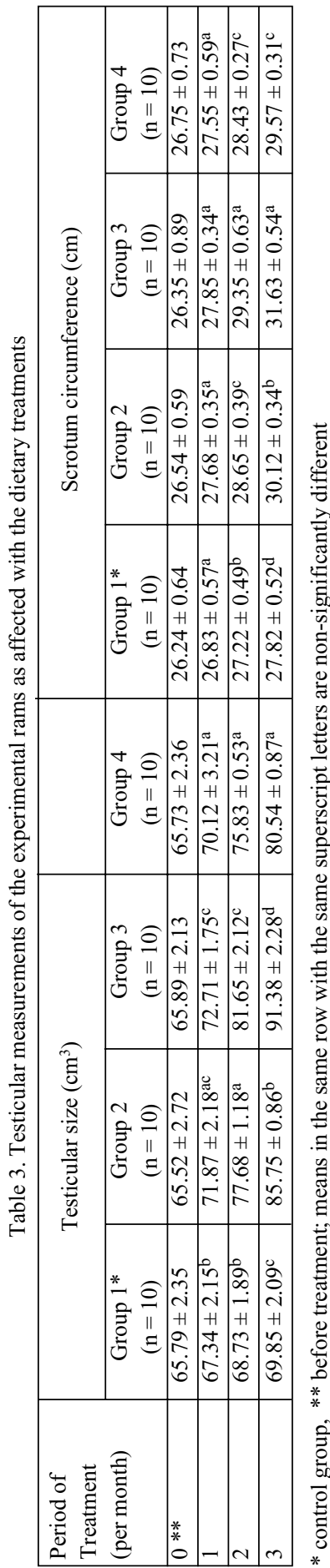

significantly in the group fed sugar cane tops after 30 days when compared with the control group (wheat straw) and the sugar cane bagasse group. After 60 - 75 days, the testosterone levels were significantly increased in the treated groups (corn cobs and sugar cane tops) compared toe controls. At the end of the study, there was a significantly higher level of testosterone in all treatment groups compared with controls. The effects of agricultural byproducts on the semen quality of the treated and control rams are presented in Tables 5 and 6 . The ejaculate volume increased significantly $(p<0.01)$ in rams fed sugar cane tops and corn cobs, compared to control, and sugar cane bagasse groups after 2 months. However, the differences in the ejaculate volume was significant $(p<0.01)$ between treatment and control group and within the treated groups (Table 5) at the end of the experiment. Furthermore, the total sperm abnormalities significantly decreased $(p<0.01)$ in treated groups compared with controls. In addition, live sperm percentage and individual sperm motility percentage significantly increased $(p<0.01)$ after $2-3$ months in treated animals, and differences were also found within groups (Table 6).

Pregnancy rate improved in treated groups compared to the control group (Table 4), and it was also higher in ewes mated by rams supplemented with sugar cane tops $(86.67 \%)$ compared to those mated by rams fed corn cobs $(83.33 \%)$, sugar cane bagasse $(81.48 \%)$ and wheat straw $(74.07 \%)$.

\section{Discussion}

The present study was conducted to monitor the effect of feeding agricultural byproducts on the live body weight, testicular size (TS), scrotal circumference (SC) as well as the variation of testosterone levels and semen quality along with the pregnancy rate in ewes mated by the treated rams. It demonstrated an increasing effect in the live body weight, TS, SC and serum concentrations of testosterone. The live body weight and daily body gain of treated rams significantly increased $(p<0.01)$. On the other hand, these types of roughage contain high levels of crude protein (13.73 and $11.35 \%$, respectively) as a result of adding $1 \%$ urea. These results are in agreement with Rea et al. (1998), who mentioned that the body weight of bulls that fed on the same rations increased, compared to bulls fed rations with low crude protein levels. Skiba et al. (1998) reported the same results in pigs.

The increase of daily body gain in treated rams might be attributed to the addition of urea (1\%, according to Agriculture National Research Council, 1992), which improved the nutritive value of the used roughage (E1- 
Table 4. Testosterone concentration (means $\pm \mathrm{SE}, \mathrm{ng} / \mathrm{ml}$ ) in rams blood serum and pregnancy rate in mating ewes

\begin{tabular}{|l|l|l|l|l|}
\hline $\begin{array}{l}\text { Period of } \\
\text { treatment (per days) }\end{array}$ & $\begin{array}{c}\text { Group 1* } \\
(\mathrm{n}=10)\end{array}$ & $\begin{array}{l}\text { Group 2 } \\
(\mathrm{n}=10)\end{array}$ & $\begin{array}{c}\text { Group 3 } \\
(\mathrm{n}=10)\end{array}$ & $\begin{array}{c}\text { Group 4 } \\
(\mathrm{n}=10)\end{array}$ \\
\hline $0^{* *}$ & $1.31 \pm 0.24$ & $1.27 \pm 0.23$ & $1.32 \pm 0.17$ & $1.29 \pm 0.22$ \\
\hline 15 & $1.41 \pm 0.15^{\mathrm{a}}$ & $1.49 \pm 0.14^{\mathrm{a}}$ & $1.62 \pm 0.13^{\mathrm{a}}$ & $1.42 \pm 0.08^{\mathrm{a}}$ \\
\hline 30 & $1.51 \pm 0.11^{\mathrm{b}}$ & $1.62 \pm 0.21^{\mathrm{ba}}$ & $1.76 \pm 0.09^{\mathrm{a}}$ & $1.54 \pm 0.12^{\mathrm{b}}$ \\
\hline 45 & $1.54 \pm 0.06^{\mathrm{b}}$ & $1.69 \pm 0.10^{\mathrm{ba}}$ & $1.85 \pm 0.07^{\mathrm{a}}$ & $1.55 \pm 0.16^{\mathrm{b}}$ \\
\hline 60 & $1.59 \pm 0.11^{\mathrm{c}}$ & $1.88 \pm 0.09^{\mathrm{b}}$ & $2.09 \pm 0.19^{\mathrm{a}}$ & $1.67 \pm 0.14^{\mathrm{c}}$ \\
\hline 75 & $1.69 \pm 0.13^{\mathrm{c}}$ & $1.99 \pm 0.07^{\mathrm{b}}$ & $2.15 \pm 0.15^{\mathrm{a}}$ & $1.78 \pm 0.11^{\mathrm{c}}$ \\
\hline 90 & $1.76 \pm 0.09^{\mathrm{c}}$ & $2.18 \pm 0.31^{\mathrm{b}}$ & $2.35 \pm 0.24^{\mathrm{a}}$ & $1.97 \pm 0.16^{\mathrm{d}}$ \\
\hline Pregnancy rate & $74.07 \%$ & $83.33 \%$ & $86.67 \%$ & $81.48 \%$ \\
\cline { 2 - 5 } & $(20 / 27)$ & $(25 / 30)$ & $(26 / 30)$ & $(22 / 27)$ \\
\hline
\end{tabular}

* control group, ** before treatment; means in the same row with the same superscript letters are non-significantly different

Saadauy 1991; Matter et al. 1995). Moreover, urea can be converted by microbial activity in the rumen into amino acids (Banks 1981). A large part of dietary protein is degraded into ammonia in the rumen. Fermentation of a variable amount of ammonia together with ammonia from the endogenous source is incorporated into microbial protein (Chen and Orskov 1994). Degradation of dietary protein depends on its fermentation and its retention time in the rumen. Roughage (as used in this study) has a very long retention time (Orskov 1992). The ammoniated roughage could have improved the productive performance of the rams (El-Azab et al. 1996).

The present work indicated that animals fed sugar cane tops and corn cobs had a significantly higher glucose level and a significantly lower total cholesterol level in blood. This result corresponded with those reported by Guy ton (1991) and Gan ong (1995). They mentioned that the increase of the basal metabolic rate is accompanied by an increase in the glucose level and a decrease in the total cholesterol level. This may be due to the formation of low-density lipoprotein receptors in liver cells resulting in the removal of total cholesterol from the circulating blood, while the increase in the glucose level can be attributed to the increase in the rate of absorption of carbohydrates from the gastrointestinal tract. In addition, the increase in the glucose concentration in the blood may be a result of the increase in formation of propionic acid in the ruminant stomach due to fermentative process (Banks 1981).

As regards the effect of agricultural byproducts with crude protein on the testicular measurements and testicular function, dietary protein is necessary for a normal body function and it is required for the production of vital cell components, and it is critical to cellular function (Reilly and Rombean 1994). Furthermore, any deficiency of protein may result in retarded testicular growth and reduced androgen production (Thwaites 1995ab). These reports support our results which revealed that testicular measurements (TS and SC) significantly increased in groups fed high crude protein (sugar cane tops and corn cobs) compared to those in other groups. In these groups with a higher crude protein level a significant increase of testosterone concentration was found. This result is in agreement with reports by Martin et al. (1994), and O'Callaghan and Boland (1998). They mentioned that, dietary protein deprivation in rams accompanied by suppression of the testicular endocrine function reduced testosterone concentrations. The increased concentration of testosterone found in the present study may be attributed to the increased protein intake in diet, which leads to the activation of the hypothalamic-pituitary axis. This activation further stimulates the release of pituitary gonadotrophins (Martin et al. 1994), which leads to 


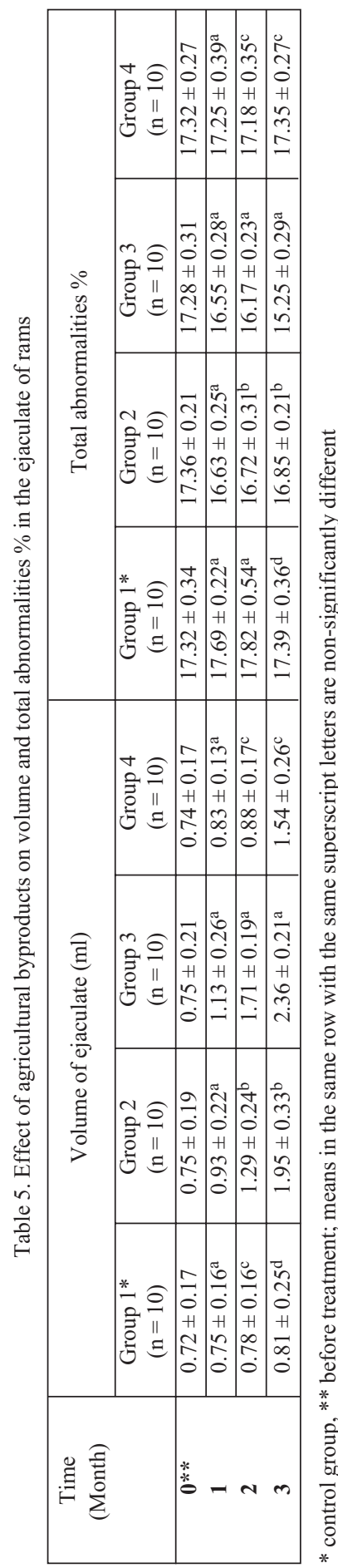

increasing activation of interstitial (Leydig's) cells. These cells have a number of LH receptors. A full physiological response occurs when the receptors are occupied by the $\mathrm{LH}$ hormone (Bender 1993).

Regardless of the improvement of semen quality and pregnancy rate, the obtained results may be attributed to the basic protein, which finally replaced by protamines as well as, persist in liberating the spermatozoa (Lamming 1990) and increase the volume of the ejaculate. However, deficiency leads to a depression or cessation of spermatogenesis and a decreased quality of semen (Hurley and Doane 1989).

In conclusion, it is apparent from the present study that the dietary supplementation of agricultural byproducts treated with $1 \%$ urea had beneficial effects on the body weight, daily body gain as well as the reproductive performance. Moreover, the treated roughage increased significantly the testosterone production as well as improved the semen quality, which lead to an increase in the rams' fertility reflected in the increased pregnancy rate of ewes mated by the treated rams.

\section{Vliv vedlejších zemědělských produktů na přírůstky a reprodukci beranů plemene Saidi}

Byl zkoumán vliv přídavku vybraných vedlejších zemědělských produktů do krmné dávky na přírůstky, reprodukční schopnosti a následnou plodnost beranů. Čtyřicet beranů plemene Saidi bylo rozděleno do 4 skupin $(n=10)$. Berani skupiny 1 (kontrola) byli krmeni 500 g jádra- směsí koncentrátu (CFM) na den a měli k dispozici pšeničnou slámu ad libitum. Berani skupin 2, 3 a 4 byli krmeni 500 g jádra - CFM na den spolu s kukuřičnou drtí nebo natí cukrové třtiny či výlisky cukrové třtiny (tato krmiva byla ošetřena $1 \%$ močovinou). Každých 15 dní byly zjištovány sérové koncentrace testosteronu, glukózy, cholesterolu a bylo vyhodnocováno semeno. Každý měsíc byly zaznamenávány velikost varlat, obvod šourku a hmotnost beranů. Na konci experimentu bylo 114 zdravých bahnic připuštěno 12 ti z těchto beranů $\mathrm{k}$ vyhodnocení plodnosti každé skupiny.

Výsledky ukázaly, že se stoupajícím věkem se u pokusných skupin ve srovnání s kontrolní skupinou zvyšovala hmotnost, denní prírůstek, zvětšovala varlata a obvod šourku $(p<0,01)$. Na konci experimentu (po 90 dnech) byly u pokusných skupin v porovnání s kontrolní skupinou větší varlata a obvod šourku $(p<0,01)$. Koncentrace testosteronu se $\mathrm{u}$ těchto skupin oproti kontrolní skupině $\left(1,76 \pm 0,09 \mathrm{ng} \cdot \mathrm{ml}^{-1}\right)$ signifikantně zvýšila (skupina 2: $2,18 \pm 0,31 \mathrm{ng} \cdot \mathrm{ml}^{-1}$; skupina 3: 2,35 $\pm 0,24 \mathrm{ng} \cdot \mathrm{ml}^{-1}$ a skupina $\left.4: 1,97 \pm 0,16 \mathrm{ng} \cdot \mathrm{ml}^{-1} ; p<0,01\right)$. 


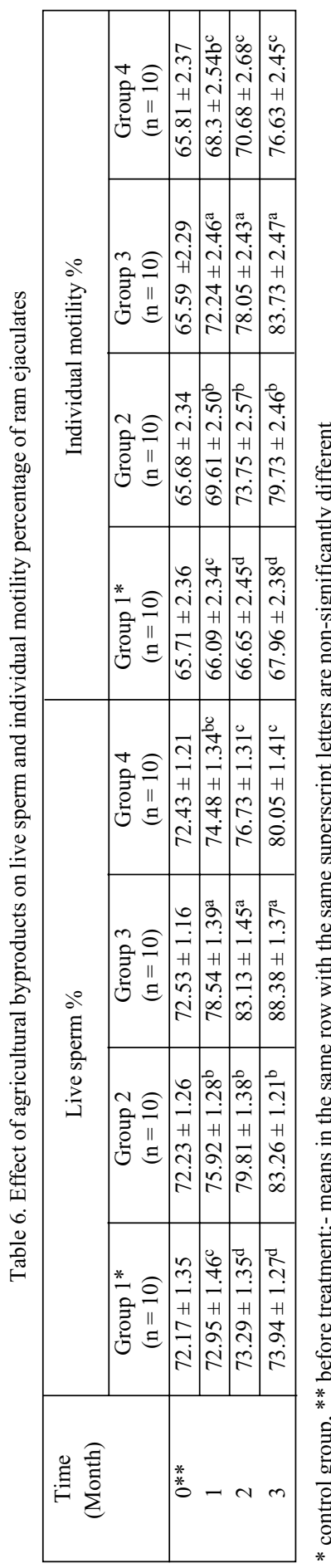

Přídavek vedlejších zemědělských produktů měl navíc signifikantně pozitivní vliv na kvalitu semene. Objem semene se zvýšil spolu s individuální motilitou a procenty živých spermií. Vyšší procenta březích bahnic po připuštění berany ze skupin 2,3 a 4 poukazují na lepší plodnost pokusných skupin $(83,33 \%, 86,67 \%$ a $81,48 \%)$ ve srovnání s kontrolní skupinou (74,07\%).

Vedlejší zemědělské produkty, jako je kukuřičná drt, nat cukrové třtiny a výlisky cukrové trrtiny ošetřené $1 \%$ močovinou, měly ve srovnání s pšeničnou slámou pozitivní vliv na denní přírůstky, zlepšily reprodukční schopnosti beranů a zvýšily následnou plodnost beranů plemene Saidi.

\section{References}

ABDEL-GHANI AA, EL-BARODY MAA, SAAD OAO 1995: Milk yield and composition, blood metabolites and rumen activity as affected by different levels of Saccharomyces cerevisiae plus growth medium supplementation in Egyptian buffaloes. $5^{\text {th }}$ Sci. Conf. Animal Nutrition. Ismailia University Vol. 1: 115-128

Agriculture National Research Council 1992: Nutrient Requirements of Sheep. National Academy Press, Washington, D.C. pp 9 - 11

BANKS WJ 1981: Applied Veterinary Histology. Williams and Wilkins, Baltimore USA

BENDER DA (ed.) 1993: Hormonal control of metabolism. In: An Introduction to Nutrition and Metabolism. UCL Press Limited, London, pp. 219-226

BURGER AG, O'CONNELL M, SCHEIDEGGER K, WOOD R, DANFORTH E, JR. 1987: Mono-deiodination of triiodothyronine and reverse triiodothyronine during low and high caloric diets. J Clin Endocrin Metab 65: 829

CHEN X, ORSKOV ER 1994: Amino acid nutrition in sheep. In: Amino Acids in Farm Animal Nutrition. J.P.F. D'Mello (Ed), CAB International, Wallingford. UK, pp. 307-328

EL-AZAB AI, KHADR NA, ZAHRAN K 1996: Effect of the nonprotein nitrogen in the ration on the semen quality of growing rams. $8^{\text {th }}$ Annual Congr. Egypt. Soc. Anim. Reprod. Fertil., Cairo, Egypt. pp. 86-93

EL-SAADAUY F 1991: Utilization of economical sources of nutrients in animal nutrition. Ph. D. Thesis, Fac. Agric, Cairo University

GANONG WF 1995: Thyroid gland. In: Review of Medical Physiology. $7^{\text {th }}$ Ed., Appleton and Lange California, Libraire du Liban, Beirut Lebanon, pp. 290-305

GORDON I (Ed.) 1997: Ram fertility and breeding activity. In: Controlled Reproduction in Sheep and Goats. CAB International. Wallingford, UK. pp. 20-30

GUYTON AC 1991: The thyroid metabolic hormones. In: Medical Physiology. $8^{\text {Th }}$ Ed. W.B. Saunders Company, Harcourt Brace Jovanovich, Inc. Philadelphia, London, pp. 831-841

HABEEB AA, MARAI IFM, DOODER AH, YOUSEF HM 1995: Effect of diet supplementation and body cooling on heat stressed friesian calves reared under Eastern Desert of Egypt. $5^{\text {th }}$ Sci. Conf. Animal Nutrition. Ismailia University Vol. 1: 39-49

HURLEY WL, DOANE RM 1989: Recent developments in the roles of vitamins and minerals in reproduction. J Dairy Sci 72: 784-804

LAMMING GE (Ed.) 1990: Physiology of the Mammalian Testis. $4^{\text {th }}$ Ed. Vol.2, Churchill Livingstone, New York, pp. 40-54 
MARTIN GB, TJONDRONEGORO S, BLACKBERRY MA 1994: Effects of nutrition on testicular size and the concentrations of gonadotrophins, testosterone and inhibin in plasma of mature male sheep. J Reprod Fertil 101: 121-128

MATTER BB, MAHMOUD AM, KUORET IS, ABOU-SELIM JA 1995: Effect of feeding various sources of nonprotein nitrogen on performance of lactating Friesian cow. $5^{\text {th }}$ Sci., Confer. Anim. Nutrition, 1:1-10, Ismailia University

MURRAY PJ, ROWE JB, PETHICK DW 1991: Effects of Season and nutrition on scrotal circumference of Merino rams. Aust J Exper Agric 31: 753-756

O'CALLAGHAN D, BOLAND MP 1998: Nutritional influences on the hormonal control of reproduction in ruminants. EAAP $49^{\text {th }}$ Annual Meeting, Warsaw, Poland, P158

ORSKOV ER 1992: Protein Nutrition in Ruminant. $2^{\text {nd }}$ Ed. Academic Press, London

RAE AL 1986: Selection for reproductive performance and hereditary aspects of sheep reproduction. In: Current Therapy in Theriogenology. DA Morrow (Ed.), WB Saunders Co., London, Philadelphia, pp. 841-843

REA RE, MAY BJ, ENGDAHL GR, SHELBY DR, SCOTT CB 1998: Effect of protein sources on performance of weaned Bulls. J. Anim. Sci. 76 (Suppl.1) p. 253

REILLY KJ, ROMBEAN JL 1994: Protein source in internal nutrition. In: Dairy Products in Human Health and Nutrition. MR Sastre, MA PerezJuez, A Estrala and C Desebastian (Eds), A.A. Balkema, Brodkfield, USA, pp. 245-253

SHELTON M 1995: Harnessing the biological potential of sheep in providing protein for growing world population. J Anim Sci 73 (suppl.1) p. 243

SKIBA G, FANDREJEWASKI H, RAJ S, WEREMKO D 1998: Growth performance, protein utilization and body composition of $15-20 \mathrm{~kg}$ pigs in relation to their nutrition from $12-25 \mathrm{~kg}$. EAAP $49^{\text {th }}$ Annual Meeting, Warsaw, Poland, p. 87

THWAITES CJ 1994: The effects of feeding supplements containing different amounts and sources of nitrogen on live weight and the tests of rams during and mating. Anim Feed Sci Technol 48: 177-184

THWAITES CJ 1995a: The comparative effects of under nutrition, exercise and frequency of ejaculation on the size and tow of the testes and on semen quality in the ram. Anim Reprod Sci $37: 299-309$

THWAITES CJ 1995b: Effect of undernutrition on the size and tow of the ram's testes. Small Ruminant Res 16: 283-286

WEST DM 1986: Pregnancy diagnosis in the ewe. In: Current Therapy in Theriogenology. DA Morrow (Ed.), WB Saunders, Philadelphia. pp. 850-852 